\title{
Wrong Train to Right Destination: Romantic Journey Motif in The Lunchbox Suddhasattwa Banerjee
}

Assistant Professor in English, Hiralal Bhakat College, Nalhati, Birbhum, West Bengal, India. Email: suddhasattwabanerjee@gmail.com

\author{
Keywords \\ Theme of Journey, The Lunchbox, \\ Romantic Voyage, Ritesh Batra, Nomad to \\ Nowhere.
}

\section{Article History}

Received on $2^{\text {nd }}$ November 2021

Accepted on $13^{\text {th }}$ December 2021

Published on $16^{\text {rh }}$ December 2021

\section{Cite this article}

Banerjee, S. (2021). Wrong Train to Right

Destination: Romantic Journey Motif in

The Lunchbox. Humanities \& Social

Sciences Reviews, 9(6), 40-45.

https://doi.org/10.185 10/hssr.2021.967

Copyright @Author

Publishing License

This work is licensed under a Creative Commons Attribution-Share Alike 4.0 International License

\section{Abstract}

Purpose of the study: This paper attempts to analyze the theme of journey in The Lunchbox in the context of the varied strains of Romantic journey motifs present in $19^{\text {th }}$ Century and early $20^{\text {th }}$ Century Romanticisms prevalent in England, Germany, France, and America in the said period.

Methodology: It is primarily a revisionist study. I have attempted to place The Lunchbox in the context of Romantic literature, predominantly of the $19^{\text {th }}$ Century and early $20^{\text {th }}$ Century and meticulous textual analysis is the basic procedure for this venture.

Main Findings: The findings of this study indicate that the theme of the journey is a signature mark of Romanticism has been used in The Lunchbox for remapping geo-cultural imaginaries of contemporary Mumbai, one of the representative cities of South Asia. Journey to some exotic locale has always been considered as an added advantage to the fundamental narrative of a film.

Applications of this study: This study will be really helpful to those who want to have a clear idea of the common theme of journey present in different kinds of Romanticisms (Lovejoy, 1924) prevalent in England, Germany, France, and America in the $19^{\text {th }}$ Century and early $20^{\text {th }}$ Century. However temporally and spatially specific, this theme can transcend all the boundaries of time, space, and art form and can be traced in The Lunchbox.

Novelty/Originality of this study: The way this paper has attempted to place The Lunchbox in the context of the Romantic literature, predominantly of the $19^{\text {th }}$ Century and early $20^{\text {th }}$ Century, is quite unique, in my opinion. I have not come by any such venture especially relating this movie and the flourish of different Romantic philosophies prevalent in the mentioned segments of the globe in the said period.

\section{INTRODUCTION}

The theme of journey as a signature mark of different kinds of Romanticisms (Lovejoy, 1924) has been used in different films in different parts of the globe that too since the very initiation of the cult of film making itself. Journey to some exotic locale has always been considered as an added advantage to the fundamental narrative of a film. But in some cases, the development of film itself is guided by the theme of journey. This debut feature film by Ritesh Batra, The Lunchbox is having a kind of inherent romance which is not only apparent in the development of a virtual relationship between Mr. Saajan Fernandez, a widowed government official on the verge of retirement, and Ila, a young housewife, whose husband is involved in an extra-marital affair but is also extended all over the city of Mumbai, observed through the gaze of a common man, travelling in local trains along with a huge number of lunchboxes (dubbas) which travel long ways under the efficient guidance of the dubbawalas (Professional Carriers of Lunchboxes from homes and restaurants to offices and other workplaces in Mumbai). But an accidental lapse in spite of their expertise leads a $d u b b a$ to a wrong person, who gradually appropriates the position of the right one. In his debut film, Batra links this binary in such an efficient way that the difference between them seems irrelevant at times. This paper attempts to analyse the theme of journey in The Lunchbox in the context of the varied strains of Romantic journey motifs present in $19^{\text {th }}$ Century and early $20^{\text {th }}$ Century Romanticisms prevalent in England, Germany, France, and America in the said period.

\section{Literature Review: (Review of the film given following the suggestion)}

Ila vigorously attempts to have an entry into her husband's heart through his stomach with the help of the advices of the unseen Aunty, who stays at the flat upstairs. This vain endeavour brings out her helplessness as her conjugal relationship is beyond her control. The crisis becomes all the more apparent as she discusses the matter with Saajan, who accidentally gets the lunchbox prepared for her husband. Batra has also presented an ailing father, suffering from cancer, a distressed mother, and the memory of a younger brother who had committed suicide, to project Ila's helplessness acutely.

Ila's helplessness reaches its ultimate height. But the recollection of that journey ultimately fails to bring back her marital life to the right track. The only request placed by her husband is not to send cauliflower curry every day, as it causes indigestion. Ila's husband refers to the lunchbox meant for Saajan but wrongly delivered to him. This wrong delivery acquires an added lair of significance as it leads towards the failure of Ila's attempt to reach his heart. It is a wrong delivery by the dubbawala, but it reaches the right person, with whom Ila develops a companionship through the notes 
written on napkins placed within the dubba. It brings back the flavour of epistolary communication quite credibly in this age of online chats and electronic messaging. Ila's initial desire being to re-establish emotional communication with her husband takes a wrong turn but rightly establishes one with Saajan, who gradually comes out of the musk of harshness, he had always put on since his wife's death.

Shaikh has a journey of his own, and that too consists of the binary between elopement and marriage. However, the marriage of Shaikh was finally arranged with the due approval of the father of the bride. This journey is juxtaposed with the journey of Saajan from the solitary balcony of his Bandra Cottage to the small flat of Sheikh, sharing the warmth of the success of their conjugal relationship and watching the photographs of Shaikh's marriage. The immediate reaction of this sharing brings out the binary between his previous stance as a wronged one having a smoke in the lonesome balcony with a peeping glance at the neighbouring dining table and the smile as a guardian of Shaikh in the photograph. The exchange of notes with Ila gradually turns into emotional bonding, and Saajan's warmth for Shaikh increases to the level of guardianship both in public and in private life.

The theme of journey initially connects the wrong train and the right destination through a speech by Shaikh while standing in a crowded local train. He here brings in a fictitious mother, although he is an orphan. Being asked about it, he clarifies to Saajan that this construction of a fictitious mother brings him a sense of pleasure. Again we can trace a genuine feeling emerging with a factually wrong statement. Hence it adds a lot to the right-wrong binary. Saajan approves the feelings of Shaikh on the next day during lunch and offers Shaikh a large share of his meal prepared by Ila. The expression of Shaikh's fictitious mother can be traced in the final letter of Ila to Saajan only with the difference that it was not told to her and she had read it somewhere. The last letter Ila writes to Saajan brings out the final form of journey in Batra's film as she confirms her journey to Bhutan along with her daughter. She arranged it by selling all her ornaments, including 'mangal-sutra,' the symbol of marriage. She is completely devoid of any specific hope for the future and entirely dependent on information found in her daughter's school book that gross domestic happiness is the highest in Bhutan.

This journey is contrasted with Saajan's journey to Nasik after retirement. He, however, ultimately fails to undertake this journey, and we are not sure what happens to Ila. She previously had a journey along with her daughter in the quest for Saajan to his office and finds Shaikh in his place. Hence the aim of her journey remains unfulfilled, and the film ends with Saajan's journey with the dubbawalas in a local train in search of Ila. Batrahere clarifies the wrong delivery by the dubbawalas. It was caused by a wrongly placed address. So it remains covered with mist if Saajan and Ila at all become able to reach the right destination. It was then not only limited within the binary of track and destination. Time became immensely important as he had to reach Ila before her journey to Bhutan. Ila's prolonged wait for Saajan in a restaurant is the actual starting point of this journey. In spite of sitting in another corner, Saajan fails to face her as she is much younger and his age is no match with hers. He previously returns to the bathroom before coming out of his cottage to have a second look at himself, and the smell he finds in the bathroom resembles that of his grandfather, experienced by him in childhood. This realisation of his age arouses a question of right and wrong, and he fails in bridging the gap of a few yards in that restaurant.

Saajan's psychological journey turns him into a 'nomad' to 'nowhere' (Ghose, 1967, p. 138). I am failing to restrict myself from quoting Babbit in this context, "Actual vagabondage seemed to be an aid to the imagination in its escape from verisimilitude. One should note especially Rousseau's account of his early wandering from Lyons to Paris ..." (Babbit, 1947, p. 75). The way Saajan fails to travel the few yeards of the distance he had with Ila in the restaurant does clearly establish my argument regarding his identification with 'nowhere' as is quite commonly traced among the romantics. In this context, I would like to refer to a few lines by Nietzsche, "Where is my home? Thus ask I and seek and have sought: this have I found not. Oh, eternal Everywhere! Oh, eternal Nowhere! Oh, eternal Vain! 'The Shadow"' (Barrett, 1962). And Baudelaire states,

"And man, drunk of a shade that flies,

His punishment forever bears

For never learning to sit quiet” (Baudelaire, 1922, p. 133).

Saajan thus bears one of the fundamental trends of romanticism, in my opinion, best expressed, through the phrase, "nomad to nowhere," suggesting a plexus of meaning- ranging from 'lost travellers' to the longing for the beyond (Ghose, 1967, p. 138). Maud Bodkin, treading in the footsteps of Jung, has studied this archetypal image under the aspect of 'the night journey' as a symbolic projection of the mental states that Jung calls 'progression and regression' (Bodkin, 1951, p. 36-38). This sequence constitutes the rebirth archetype, also manifest in dreams and the vegetation god. While analysing the "Ancient Mariner" (1798), especially the rebirth archetype in it, Bodkin finds a kind of resemblance among voyage, dream, and myth. But film-narratives need not be myths nor dreams, although they often provide us with a pattern of a literary theme. The problems of myth and dream lie outside the domain of film studies. For the function of myth in the primitive community, we should better go to the philosopher rather than the cultural anthropologist. My concern, however, is with the theme of the romantic voyage in The Lunchbox. I, therefore, propose to examine it as a longing for the beyond, both in the case of Saajan and Ila.

The longing for the beyond is an old theme, not unknown to the wandering minstrels like the Sufis, Troubadours, and the Bauls (People of Bengal belonging to a specific cult irrespective of caste, creed, or religion and performing specific rites 
and musical expressions of a specific philosophy of life primarily based on renunciation) whom the love of God had rendered 'homeless.' The history of romantic literature rings with this nostalgic tremor on the trajectories of mysticism. The notion of mystic communion with the infinite is not the romantic's second nature, but her first. Blake asserts, "I assert for My Self that I do not behold the outward Creation and that to me it is a hindrance and not Action ... I Question not my Corporeal or Vegetative Eye any more than I would Question a Window concerning a Sight. I took through it and not with it". (Keynes, 1957, p. 617)

\section{METHODOLOGY AND PROCEDURE}

It is primarily a revisionist study as I have attempted to place The Lunchbox in the context of Romantic literature, predominantly of $19^{\text {th }}$ Century and early $20^{\text {th }}$ Century and meticulous textual analysis is the fundamental procedure for this venture. Romanticism basically incorporates a host of varied philosophies which differ from time to time and space to space, but a theme like a journey is common in almost all of them. Hence, I chose that to analyse quite a recent Hindi movie that shares several of the basic traits prevalent in the theme of journey in different Romanticisms.

\section{FINDINGS AND ANALYSIS}

The theme of journey in The Lunchbox in the context of the varied strains of Romantic journey motifs present in $19^{\text {th }}$ Century and early $20^{\text {th }}$ Century Romanticisms prevalent in England, Germany, France, and America in the said period can be successfully analysed. In spite of the difference in time, space, and art form, the basic theme of journey is definitely Romantic in nature.

Hence this Romantic motif is actually hinting at a journey within the Self, just as the journey of Saajan in The Lunchbox. The letters he sent with the lunchbox bring out the "Window concerning a Sight," exhibiting a definite inclination towards a mystic communion with the infinite romantic ideal. It gradually attains a corporeal frame, and Saajan only observes it from a distance as he finds himself incapable of covering it by a further journey. This incapability can be clarified in further detail by the age difference between him and Ila. Saajan's failure to proceed a few yards in the restaurant is actually caused by the event in the bathroom as it made him realise his age. Batra here brings out a kind of communion, rather confrontation, between a temporal journey and a spatial one, a journey of realisation of age and a journey of few yards in the restaurant. Interchanges between the Self and the Other are attributed with an added level of significance through a kind of mutual reception between the interior and exterior vision.

This mutual reception unfolds an important side of the Romantic longing for the Infinite. Rabindranath calls it the 'infinite longing" and makes a Bergsonian metaphysics out of this in The Religion of Man (1931). In the text, he defines human life as "the ceaseless adventure to the Endless Further" (Tagore, 1949, p. 379). This is so much more true of his poems and songs, for there, the note recurs as an intuitive element without the uneasy rhetoric of the metaphysics. Chateaubriand strikes the same note in his Rene: "Alas! I am seeking I know not what, but the urge to seek does not leave me. Is it my fault if I come up against limits everywhere and if the finite is worthless to me?” (Furst, 1969, p. 328)

The final confession of Saajan towards the end of the movie does definitely bring out almost similar expressions. In this context, references may also be made to Novalis's mysterious inner journey,

"We dream of journeys through the universe: is not the whole universe within us ... It is inwards that the mysterious path leads. Within ourselves, or nowhere, is an eternity to be found with its worlds, both past, and future. The outer world is a world of shadows, it throws its shadow into the realm of light". (Furst, 1969, p. 328)

Though it is not the conventional view, A. W. Schlegel [August Wilhelm Von Schelegel (1767-1845), a German philosopher, essayist, translator, poet, and critic] links this notion of having journey within the Self in Christianity, "In Christianity, everything has been reversed: the contemplation of the infinite has destroyed the finite; life has become a world of shadows and of darkness, and only yonder does the eternal day of true being dawn." (Furst, 1969, p. 117)

Schlegel's idea of life can explain the case of Saajan Fernandez perfectly. In this context, it is necessary to examine the Romantic's "eternal urge and unceasing exertion" a little more closely. According to T. E. Hulme [Thomas Ernest Hulme (1883-1917), a British poet, philosopher, critic and is known as the main influence behind Imagism and one of the same behind Modernism as a whole], the root of all romanticisms lies in the idea or image of man as an "infinite reservoir of possibilities." He maintains: "The view which regards man as a well, a reservoir full of possibilities, I call the romantic, the one which regards him as a very finite and fixed creature, I call classical" (Read, 1958, p. 117). Less patient than Hulme, Babbit dismisses Bergson's thesis that "life is a perpetual gushing forth of novelties" as a dangerous half-truth (Babbit, 1947, p. 75). The source of restlessness and melancholy, while a mystery to the victim, has been traced to the romantic's exclusive preoccupation with himself.

Evidently, a good deal of classicist objections against certain Romantic motifs, e.g., voyage, is a Christian strategy for non-Christian purposes. But the strategy itself may not be Christian enough. The Schlegels are known to have equated the Romantic with Christian, and the subsequent history of ideas, running through Schopenhauer and Kierkegaard to the modern existential philosophers, have tilted heavily on Romanticism. In fact, Christianity, as it is popularly practised, has never denied the space of mystery and longing for the beyond in its scheme. Therefore, what is in question is not the pertinence of the longing but its character. Not exactly in the manner of a mystic, the romantics are also amorous of the beyond; but they play secular variations on ancient devotional patterns. C. M. Bowra brings out the distinction thus, "the 
fact is that the Romantics are concerned with a mystery which belongs not to faith but to the imagination" (Bowra, 1961, p. 282). The perennial longing of the Romantics for journey operates on multiple levels. It is a longing for a liveable world, which "the soul remembers from its actual childhood" or from that vision of the Golden Age, "so deeply rooted in our ineradicable instinct for bliss" (Bowra. 1961, p. 282).

On another level, the longing for a liveable world is a reflection of failure or frustration in the present life; one regrets only out of absence, even out of ennui. It leads back to the freedom of our origin. It opens the road to salvation, either into the future or backwards, into the past through the imagination. Thomas Mann [Paul Thomas Mann (1875-1955), a German fiction writer, essayist, philosopher, social critic, and 1929 Nobel laureate in literature] has stated that the Romantic vision may also be considered an outcome of incomplete membership of any social group. Tonio Kroger's restlessness is a case in point, and so perhaps is Rabindranath's description of himself as an outcast (Tagore, 1961). In a lesser artist, however, longing degenerates into regression and a flight from responsibility just in the way Saajan avoids the responsibility in the initial part of the movie. At this juncture, we find Batra coming up with another dimension of the theme of a journey with the character of Shaikh, most attractively played by Nawazuddin Siddiqui. Shaikh, who is poised to take over the official charge from Saajan, is initially being avoided and cracked harsh jokes on. His change is to some extent sudden and is apparent towards the end of the movie.

The romantic journey motif is not without its ontology. To describe it merely as "a system of multiple longings" smacks of an unjustified simplification. A. O. Lovejoy [Arthur Onchen Lovejoy (1873-1962), an American Philosopher and Historian] has shown how Kant gives a metaphysical ballast to the notion of the 'Ideal capable' in his ethical system. (Lovejoy, 1924, p. 247) By implication, the notion of Lovejoy sanctions a passion for infinity. The whole enterprise is related to what James Murdock [An American scholar and translator (1776-1856) who translated the New Testament from Syriac Peshitta into English in 1851] describes as the rationale of post-Kantian philosophy (Feidelson, 1966, pp. 93-94) (Failed to comprehend the suggestion). This has become so much a part of modern sensibility that "complete absence of nostalgia in a modern artist," says D.W. Harding, "is suspect, suggesting complacent fellowship with the main commercial group ... or too little questioning and teasing of the tradition" (Harding, 1932, p. 12). In this context, I would like to relate it to the idea of the Christian saints, who have always related the idea of the beyond to the quest for immortality and spiritual grace, translated into secular terms, the quest survives as a search for utopia either in time or in space. One of the consequences of such secularization is that a static vision of eternity becomes involved in a powerful drive towards perfection in history. This implies an absolute faith in the future. This faith is taken to mean more of a metaphor of secular grace than a valid promise. One of the favourite variations of this metaphor with the Romantics is their ambivalent tendency towards the "prophetic past" or "remembering forwards" the land of heart's desire (Harding, 1932, p. 12).

The idyll, by definition, cannot have a definite locus in history. Nevertheless, Schiller [Johann Christoph Friedrich Schiller (1759-1805), a German philosopher, poet, and dramatist] gives it the status of a genre when he considers idyll as one of the three major categories of sentimental poetry, the other two being satire and elegy (Murdock, 2014, p. 168). The dream of Arcadia plays an overriding role in Romantic nature poetry. Although Arcadia lacks any precise locus, it is conceived as stasis. Longing determines its lineaments, and rational planning about its future would be a vulgarity. It also has a population, a special type, tending towards the higher man.

A more complex structure of secular grace involving the concept of the New Hero as part of the utopia is quite significant. Saajan in The Lunchbox attempts to fit himself in this position. In this context, the myth of grace works as a stage of the movement of an imperfect spirit towards perfection. To triumph over the shortcomings of the city of man, which is to replace the Augustine's City of God, Romantics speculate upon the possibility of an immortal being (Murdock, 2014, p. 168). But this possibility requires tremendous faith in history. Eternity must become absorbed in a temporal, natural, and historical sequence. The advent of the saviour would be one natural corollary of the utopian vision. But the saviour must enter history and act in it for a new world. The long and painful historical process of her advent is more important in the scheme than longing for an alienated unmediated vision. The romantics deal with the issue with a reverse emphasis which is apparent in Yeats's depiction of the "Second Coming" (1920) in terms of magic and mythology. Yet "The Second Coming" lacks historical advantage as it unfolds a prominent futuristic proposition. Yeats predicts a sequence of events in the natural world and this world of history. In his later poems, especially in most of the poems of The Tower (1928), Yeats's dealings with the historical time have been far from happy. He sees complexity, turbulence, and change as the entelechy of history, and these are the very categories which, he feels, either magic or pure imagination, manage to elude. Therefore, the prophetic authority of "The Second Coming" stems from a mixture of private myth and romantic longing.

William Barrett finds a parallel of Nietzsche's Superman in Faust of the second part of Goethe's poem (Barrett, 1962, p. 190). Nietzsche's Superman has more of a coherent system when placed within the German or Prussian cultural context and is not ahistorical. In this scheme of things, we find the concept of a striving individual dwelling on the mountain-top of the spirit alternates with an ancient and vaguely pagan ideal of a joyous, guiltless, free human being in possession of instincts. But at the same time, it bears an inherent contradiction, and the source of the contradiction lies in the Romantic longing for a journey beyond harsh reality. The vision of secular immortality in the Romantic imagination assumes qualities of remoteness, inaccessibility, and unreality that have characterized the quest for spiritual grace from the beginning. The search turns into longing and expectation. This Romantic faith in utopia or Superman is evidently a form of a journey across unfamiliar terrain to an uncertain destination. Confronted by history as happenings, the Romantics 
shift their emphasis suitably upon the expectation of a secular perfection. Saajan behaves in the same way and attempts to fabricate his expectations from life with similar perfection bearing the profound influence of the newly formed family of Shaikh, the junior colleague.

The Romantics are more at home in the world of imagination which Coleridge defines as the highest form of selfconsciousness. It is not "a kind of being, but a kind of knowing, and that too the highest and farthest that exists for us" (Watson, 1956, p. 155). This is man's experience of life as an individual rather than as a member of society. The experience - known to all Romantics - also implies a journey for exploration. Odysseus, Oedipus and Faust are, at heart, wanderers. Paradise lost, the Romantics are no longer at home among the "structure of the already known" (Watson, 1956 , p. 155). Each is marked by a strong responsibility for making it new. The Romantic artist recreates and rationalizes his sense of displacement in the image of the voyage. Commenting on the dream scene in the fifth book of Wordsworth's The Prelude (1805), W. H. Auden recognizes the Romantic wanderer as a double-natured hero. He is half-Bedouin, that is, "Ishmael, the exile, the wandering Jew, the Flying Dutchman" and half- Don Quixote, "the dedicated man, the knight of faith who would restore the age of Gold" (Auden, 1951, p. 18). Essentially a romantic figure, the voyager or quester has his counterparts also in myths and classical literature, the patterns of which are quite vividly apparent in Saajan's journey.

The realms of a romantic voyager are either the ocean or the desert, both of which suggest wilderness, the place where there is no community, just or unjust, and no historical change, for better or for worse. Whether on land or sea, the journey defines the mode of the existence of the voyager. Batra presents Saajan's mode of existence through his journey of life and does it quite consistently throughout the movie. The voyage that initiates man's adventure in reality, or his escape from it, suggests a plenum of significance. Noah was a voyager, and irresponsible Jonah enlarged the possibilities of travel. Explorers too, leaving home for various reasons, found the rough seas congenial. Ship and sea allow varieties of meaning that tradition had confirmed. The perpetual motion of the sea, its vast spatial dimension, and its depth make it a natural symbol of primitive potentiality and destruction. It is both a mystery and danger, and voyaging on it is our strange necessity: "From fairy tales, where the third son sets out to do what his elders failed at, and the quest for the Grail to the detective story which too is in a way a quest for 'innocence,' we encounter life as voyage on every level" (Tagore, 1961).

A perfect analysis of Saajan's journey of life necessarily requires a clarified distinction between the Romantic voyage and its mythical and classical counterparts. W. H. Auden examines it at length in The Enchanted Flood (1951). In early times, he says, voyaging - neither voluntary nor pleasant- seemed a necessary evil:

"Neither Odysseus nor Jason goes to sea for the sake of the voyage; the former is trying to get home ... the later is trying to capture the Golden Fleece, which is in a distant country, to bring back to his own. If it were nearer and voyage were necessary, he would be much relieved" (Auden, 1951, p. 73)

The journey on land, adopted by the Christians as a way of presenting the ups and downs of spiritual life, is found in The Pilgrim's Progress (1678). Dante projects human life as a quest for blessedness and spiritual grace. Shakespeare comes quite handy if we have to develop a link between this classic attitude and the Romantic. G. Wilson Knight has studied these antithetical patterns in The Shakespearian Tempest (1932). In the last plays particularly, the sea voyage plays an important role. The wandering on the sea is not yet voluntarily entered upon as a pleasure. It now becomes purgatorial suffering that must be accepted or endured. In The Winter's Tale (1623), Camillo advises the young lovers, Flozel and Perdita, to seek a settled life through the help of Leontes rather than to elope:

"A course more promising

Than a wild dedication of yourselves

To unpath'd waters, undreamed shores, most certain

To miseries enough". (Shakespeare, 1623/2021)

\section{CONCLUSION}

The link between the Romantic journey motif and the Classic depiction of ethics and value- system unfolds the theme of journey in The Lunchbox with utmost perfection. The voyage answers a variety of needs. Emerson speaks of the advance of the mind "into the recess of being, to some new frontier as yet unvisited by the elder voyagers" (Feidelson, 1966, p. 16). To some, like Captain Nemo in Jules Verne's Twenty Thousand Leagues Under the Sea (1870), finds in the sea a particular voyage, an elaborate synecdoche for life in general, since going to sea permits exploration of self and reality. To the romantic voyagers, the shore life is always trivial, and as Baudelaire [Charls Pierre Baudelaire (1821-1867) a French poet, essayist, and art critic] says:

“... the true travellers are those who go

Just to be going: like balloons, their hearts

Cannot escape their buoyant doom, and though

They don't know why, they always say; Let's start!” (Baudelaire, 1947) 
At the end of The Lunchbox, when we find Saajan travelling to Nasik following the rejection of the opportunity to settle down with all possible attainments concerning it, we can clearly understand that he is a Romantic voyager in true sense and the theme of journey in The Lunchbox is also truly Romantic in nature. Batra has always added foils to intensify it. We find Shaikh settled down happily and Ila waiting for Saajan in the restaurant, but the journey of Saajan's life rejects all possibilities to stop and rest but has always said, "Let's start," just like any voyager of truly Romantic nature. Thus, I have attempted to justify my opinion that the film, The Lunchbox is definitely Romantic in nature, and the theme of journey is the central theme of this film.

\section{LIMITATION AND STUDY FORWARD}

In this paper, I have attempted to discuss varied strains of Romanticisms (Lovejoy, 1924, p. 233), especially in connection with the theme of the journey for comparing those strains with that present in The Lunchbox. I have primarily covered the strains of England, Germany, France, and America, but there are several other strains of Romanticism present in East European countries, in South East Asia, in Australia, and in several other parts of the globe, which I failed to incorporate in my study. There are varied kinds of Romantic journey motifs that can be discussed in connection with the film of my choice.

\section{ACKNOWLEDGEMENT}

I was mostly helped by Prof. Soma Banerjee, Professor, Department of English, Rabindra Bharati University, Kolkata. She was my Ph.D. supervisor and helped me by providing all the books I referred here from her personal collection. She is a real inspiration for me.

\section{REFERENCES}

1. Auden, W. H. (1951). The Enchafed Flood. London: Fabre and Fabre.

2. Babbitt, I. (1947). Rousseau and Romanticism. Boston and New York: Houghton Mifflin.

3. Barrett, W. (1962). Nietzsche. Irrational Man. Anchor Books: New York.

4. Baudelaire, C. (1922). Countries of the Mind. (C. F. Maclntyre, Trans.). London: W. Collins Sons and Co.

5. Baudelaire, C. (1947). One Hundred Poems from Les Fleurs Du Mal. (C. F. Maclntyre, Trans.). Berkeley: University of California Press.

6. Bodkin, M. (1951). A Study of 'the Ancient Mariner' and of the Rebirth Archetype. Archetypal Patterns in Poetry. London: OUP.

7. Bowra, C. M. (1961). Romantic Imagination. London: OUP.

8. Coleridge, S. T. (1956). Biographia Literaria. Watson, G. (Ed.). London: Everyman's Library.

9. Feidelson, C. (1966). Symbolism and American Literature. Chicago and London: Chicago UP.

10. Furst, L. R. (1969) Romanticism in Perspective. London: Macmillan.

11. Ghose, S. (1967). Home-thoughts on Poetry: a Note. Someeksa: Indian Renaissance Number; Madras: India.

12. Harding, D. W. (1932). A Note on Nostalgia. Scrutiny Vol I. Cambridge.

13. Hulme, T. E. (1958). "Romanticism and Classicism"; Speculations: Essays on Humanism and Philosophy of Art. (H. Read, Ed.). London: Routledge and Kegan Paul.

14. James, W. (1955). Pragmatism and Four Essays from the Meaning of Truth. London: Meridian Books.

15. Keynes, G. (1957). A Vision of the Last Judgement. W. Blake, (Ed.) Complete Writings. London and New York: Nonesuch Press.

16. Knight, W. G. (2002). The Shakespearean Tempest: with a Chart of Shakespeare's Dramatic Universe. London and New York: Taylor and Francis.

17. Lovejoy, A. O. (1924). On the Discrimination of Romanticisms. Publications of the Modern Language Association of America. London: Cambridge University Press. https://doi.org/10.2307/457184

18. Murdock, J. (2014). Sketches of Modern Philosophy, Especially among the Germans (1846). London: Kessinger Publishing.

19. Shakespeare, W. (2021). The Winter's Tale. (B. A. Mowat \& P. Werstine, Eds.). London: Simon and Schuster.

20. Tagore, R. (1949). The Religion of Man. London: George Allen and Unwin.

21. Tagore, R. (1961). Patraput. Rabindra Rachanabali, Vol. 11, Centenary Edition, Kolkata: Government of West Bengal.

22. Tagore, R. (1961). Sesher Kabita. Rabindra Rachanabali, Vol. 9, Centenary Edition, Kolkata: Government of West Bengal. 